\title{
Development of a nutritionally balanced pizza as a functional meal designed to meet published dietary guidelines
}

\author{
Emilie Combet ${ }^{1}$, Amandine Jarlot ${ }^{1}$, Kofi E Aidoo ${ }^{2}$ and Michael EJ Lean ${ }^{1, *}$ \\ 'Human Nutrition, School of Medicine, College of Medical, Veterinary and Life Sciences, University of Glasgow, \\ Walton Building, Glasgow Royal Infirmary, Castle Street, Glasgow G4 OSF, UK: ${ }^{2}$ Food Research Laboratory, \\ Department of Life Sciences, Glasgow Caledonian University, Glasgow, UK
}

Submitted 20 May 2013: Final revision received 12 August 2013: Accepted 25 August 2013: First published online 280 0ctober 2013

\begin{abstract}
Objective: To develop a worked example of product reformulation of a very popular 'junk food' to meet nutritional guidelines for public health in a ready meal. Design: Indicative survey of popular Margherita pizzas, followed by product reformulation, applying dietary guidelines to generate a single-item pizza meal containing $30 \%$ daily amounts of energy and all nutrients. An iterative process was used; first to optimize nutrient balance by adjusting the proportions of bread base, tomato-based sauce and mozzarella topping, then adding ingredients to provide specific nutrients and consumer tasting.

Setting: Urban areas of contrasting socio-economic status.

Subjects: Untrained unselected adults ( $n$ 49) and children ( $n$ 63), assessing pizza at tasting stations.

Results: Most commercial pizzas provide insufficient information to assess all nutrients and traditional Margherita pizza ingredients provide insufficient Fe, Zn, iodine, and vitamins $\mathrm{C}$ and $\mathrm{B}_{12}$. Energy content of the portions currently sold as standard range from 837 to $2351 \mathrm{~kJ}$ (200 to $562 \mathrm{kcal}$ ), and most exceed $30 \%$ Guideline Daily Amounts for saturated fat and Na when a $2510 \mathrm{~kJ}$ (600 kcal) notional meal is considered. The 'nutritionally balanced pizza' provides the required energy for a single-item meal $(2510 \mathrm{~kJ} / 600 \mathrm{kcal})$, with all nutrients within recommended ranges: $\mathrm{Na}(473 \mathrm{mg}, \sim 45 \%$ below recommended level), saturated fat ( $<11 \%$ energy) and dietary fibre $(13.7 \mathrm{~g})$. Most adults $(77 \%)$ and children $(81 \%)$ rated it 'as good as' or 'better than' their usual choice.

Conclusions: Nutritional guidelines to reduce chronic diseases can be applied to reformulate 'junk food' ready meals, to improve public health through a healthby-stealth approach without requiring change in eating habits.
\end{abstract}

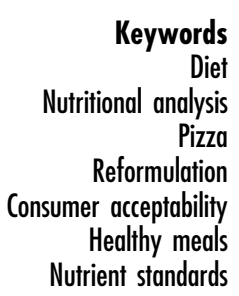

Within contemporary culture, the pizza is commonly regarded as a classic example of a 'junk food' satisfying a need for convenience (low cooking skills requirement, perceived value for money, short preparation time $)^{(1,2)}$. Historically, pizza was made from bread, with tomatoes and a little cheese. It should thus be a low-fat meal containing at least one portion of fruit or vegetable. Moreover, key pizza ingredients have been associated with improved cardiovascular health and cancer ${ }^{(3,4)}$. However, to enhance flavour, palatability and ultimately consumer acceptance, pizza recipes include higher proportions of cheese and salt than desirable ${ }^{(5)}$. It is also perceived as fattening, energy-dense and harmful for the heart $^{(4)}$. As a cheap, mass-produced food, pizza is also assumed to contain poor-quality ingredients and additives. While many pizzas are high in salt ${ }^{(6)}$, their impact on human nutrition does not seem to have been studied, a problem compounded by the limited availability of nutritional content information for commercial pizzas.

As pizzas available on the market are currently mostly nutritionally undesirable, frequent consumption of this single food could result in adverse health effects. Improving pizza compositions (inter)nationally could therefore have a valuable impact on ill-health. Indeed, this strategy was earmarked by Combris et al. as a potential tool to improve public health ${ }^{(7)}$ and food reformulation is a major feature of the Department of Health's 'Responsibility Deal' (England), engaging the food industry to deliver public health goals ${ }^{(8)}$. Reformulation of commonly eaten foods is a key approach to achieving the goals set by the WHO/FAO expert consultation ${ }^{(9,10)}$. Pizza is one of the most popular ready meals, particularly favoured by adolescents and young adults ${ }^{(11)}$. The cheese and tomato paste (Margherita) pizza commonly appears on school meal 
menus as a daily 'safe' option, being almost universally liked and accepted. Highly flavoured, warming and filling, pizzas also present advantages for mass catering as a finger food which can be pre-prepared, kept chilled or frozen and chosen as a ready meal, street food or 'carry out'.

Hitherto, food reformulation efforts have mainly addressed single nutrients, such as salt or trans-fatty acids reduction, and many essential micronutrients underconsumed by the population have been overlooked ${ }^{(8)}$. Their contents are not required on food labels. Pizza can be served either as a complete single-item meal or as a part or course of a multi-component meal, and this flexibility has also led to it being considered recently as a potential 'functional food' ${ }^{,(12)}$. There is scope to undertake reformulation of the pizza beyond salt and saturated fat reduction, to impact on the quality of the meal as a whole. The flexibility in the recipe, especially regarding topping choices and to a lesser extent modification of the dough recipe, also enables the introduction of functional ingredients to achieve an improved nutritional composition $^{(12)}$.

In order to interpret the nutrient contents of meals, it is necessary to relate them to the recommended sizes and compositions of meals and to the recommended nutrient composition of overall diets. The UK Food Standard Agency's (FSA) criterion for the size of a complete meal (potentially including a drink and a dessert as well as side dishes) equates to the amount of food which provides $30 \%$ of the recommended daily energy intake (about $2510 \mathrm{~kJ}$ or $600 \mathrm{kcal})^{(13)}$. Initially formulated for situations in which all foods were provided (institutions), it can be extrapolated for specific meals, with the caveat that supply of nutrients may not be uniform over the day. This amount of food, and proportional amounts of nutrients, is a third of the Guideline Daily Amounts (GDA, providing an indication of how much energy and nutrients can be consumed daily, to be renamed Reference Intakes from 2014 onwards) and is very similar to those as used in the Scottish nutritional recommendations for school meals ${ }^{(14)}$, summarized in Table 1. For most nutrient recommendations, differences between age groups are small, with no hazard from consumption of the 'adult' recommendation by a child. The important exceptions to this are energy and $\mathrm{Na}$, where there are marked differences in requirement and where overconsumption would have adverse consequences. Therefore, meals designed for, or marketed towards, schoolchildren need to match their nutritional requirements and also their safe limits with regard to energy and $\mathrm{Na}$.

We have previously shown that the energy content of other ready meals is erratic (inconsistent and wide ranging within similar lines of products) and that their nutrient composition is often unsatisfactory ${ }^{(2)}$. In the present paper, we first assess the dietary quality of an indicative selection of contemporary pizzas and then demonstrate how a single-item pizza meal can be redesigned to match the characteristics for a healthful meal according to recently published guidelines. We use the popular Margherita pizza for proof of concept.

\section{Methods}

\section{Nutritional composition of commercially available pizzas}

An indicative selection of twenty-five popular Margherita pizzas from UK/international suppliers, the most popular variety, was included in the present study. A full survey of all pizzas would be impractical, so the pizzas chosen were those available from major food outlets including pizza chains and supermarkets (fresh and frozen sections) as well as pizza recipes provided on popular Internet sites (bbcgoodfood.com and allrecipes.co.uk) between June 2011 and October 2011. The selection also includes a pizza (Cosmo Products Ltd) which is supplied as $60 \%$ of school-meal pizzas in Scotland and for which the detailed recipe was made available.

Nutrient composition of the range of pizzas was explored based on manufacturer information (either on the packaging or the recipe), related to current dietary recommendations ${ }^{(13,14)}$. The data are reported for the normal portion or segment size, as sold, with its energy content in $\mathrm{kJ} / \mathrm{kcal}$ and associated nutrient contents; and also the same data standardized to a 'meal-sized' $2510 \mathrm{~kJ} / 600 \mathrm{kcal}$ portion.

\section{Analysis and optimization of a commercial pizza recipe}

As a starting template from which to construct a nutritionally balanced pizza recipe, the Cosmo Products Ltd Margherita pizza recipe was analysed using WinDiets 2005 (Robert Gordon University, UK). The focus was on energy, macronutrients (total carbohydrate, non-milk extrinsic sugars, total protein, total fat and saturated fat) expressed as a percentage of energy $(\% \mathrm{E})$, fibre content (g), Na (mg)/salt (g), Fe (mg), folate (mg), Zn (mg), Ca (mg), vitamin A (mg) and vitamin C (mg). Ingredients in the recipe were adjusted to approach the guideline nutrient levels for a meal, as outlined by the UK FSA ${ }^{(13)}$.

This recipe was then adapted with the addition of some minor ingredients to finalize a 'nutritionally balanced pizza' using only natural ingredients selected for their nutritional profiles. The recipe included a mix of white and whole-wheat flour, fermented naturally with baker's yeast, rapeseed oil, minimal salt, seaweed (Seagreens ${ }^{\circledR}$ Ascophyllum nodosum), red pepper, canned and cherry tomatoes, garlic powder, oregano and mozzarella cheese.

\section{Nutritional analysis of the optimized pizza product}

Nutritional analyses on the finished product were carried out at Glasgow Caledonian University Food Research 
Laboratory, which operates to ISO 17025:2005 standards. The pizzas were produced industrially as a batch and two representative samples were randomly selected and sent to the laboratory frozen (transport time less than $1 \mathrm{~h}$ $30 \mathrm{~min}$ ), on ice blocks, with immediate transfer to $-20{ }^{\circ} \mathrm{C}$ on arrival. The pizzas were processed for analysis within a week, cooked in a domestic oven as they would be for eating, and their energy content determined from the composition of the macronutrients. All measurements were carried out in triplicate. Total carbohydrate was determined from the sum of moisture, fat, protein and ash contents. Moisture content was determined by the dry oven method at $103 \pm 3^{\circ} \mathrm{C}$ (BS 4401-3:1997; ISO 1442:1997), total fat content by drying followed by petroleum ether extraction (BS 4401-4:1970), protein by determining nitrogen $(\times 6 \cdot 25)$ by the Macro-Kjeldahl method (BS 4401-2:1980; ISO 937:1978) and ash by incinerating at $525 \pm 25^{\circ} \mathrm{C}$ (BS 4401-1:1998; ISO 936:1998). The total sugars profile (all monosaccharides and disaccharides) was determined by HPLC (AOAC Official Methods 980•13; 977•20; 982·14) and non-milk extrinsic sugars estimated by subtracting lactose and galactose ${ }^{(15)}$, dietary fibre by the AOAC method $^{(16)}$ and fatty acids by capillary GC (AOAC Official Methods 996.01; 996.06) ${ }^{(15)}$. The mineral contents (Na, $\mathrm{Ca}, \mathrm{Zn}$ and $\mathrm{Fe}$ ) were determined by atomic absorption spectroscopy ${ }^{(17,18)}$. Folate was determined by the competitive enzyme immunoassay method (R-Biopharm, 2010), vitamin C by the titrimetric method (AOAC Official Method $967 \cdot 21)^{(15)}$ and vitamin A by LC $^{(19)}$.

\section{Evaluation of the acceptability of the finisbed product}

Taste tests and acceptability evaluations were conducted with untrained members of the public (both adults and children) at two different public locations around the city of Glasgow. Acceptability of the product was established using the 9-point hedonic scale, ranging from 1 (dislike extremely) to 9 (like extremely) ${ }^{(20,21)}$. The scale was modified for children according to Kroll, and descriptors ranged from 1 ('super-bad') to 9 ('super-good') (22). The pizza was assessed for its taste and appearance, with a further scale for overall acceptability. Tasters were also asked to compare the pizza with their usual one ('not as good', 'as good as' or 'better'), whether they would buy it (adults) or eat it (children) rather than their usual one (possible answers were 'yes', 'no' and 'not sure') and were asked to describe what they liked best or liked least about the pizza. Furthermore, adults were asked how much more they would be willing to pay for a nutritionally balanced pizza.

\section{Results and discussion}

\section{Nutritional composition of a selection of Margherita pizzas}

The recommendations for a nutritionally balanced meal (Table 1) can be related to nutritional values for the twenty-five pizzas (Table 2). There was considerable variation in the nutrient composition of what might appear, from the on-label descriptions, to be the same pizza. Energy content of the portions currently sold as standard varies from 837 to $2351 \mathrm{~kJ}$ ( 200 to $562 \mathrm{kcal}$ ). Few currently approach the energy content required for a meal, even for primary-school children. Most have substantially lower serving sizes than a standard meal, implying that none would be suitable as single-item meals, and that an additional food item would be required to form a meal of about $2510 \mathrm{~kJ} / 600 \mathrm{kcal}$. No guidance was offered as to what type of additional items should be eaten to achieve a nutritionally balanced meal. Given the range of energy content ( 837 to $2351 \mathrm{~kJ}$ (200 to $562 \mathrm{kcal}$ ) per pizza portion), it will be difficult to make a consensus decision on acceptable additional meal items.

Considering that pizza is commonly eaten as a standalone meal, we also analysed the nutrient composition of

Table 1 Recommended intakes at lunches or dinners for Scottish primary-school pupils, secondary-school pupils ${ }^{(14)}$ and adults ${ }^{(13)}$

\begin{tabular}{|c|c|c|c|}
\hline & $\begin{array}{l}\text { Primary-school pupils aged } \\
5-11 \text { years }^{(14)}\end{array}$ & $\begin{array}{c}\text { Secondary-school pupils aged } \\
11-16 \text { years }^{(14)}\end{array}$ & Adults aged $19-55$ years $^{(13)}$ \\
\hline Energy (kJ) & 2330 & 2791 & 2510 \\
\hline Energy (kcal) & 557 & 667 & 600 \\
\hline Protein (\%E) & $>12$ & $>12$ & $>12$ \\
\hline $\mathrm{CHO}(\% \mathrm{E})$ & $45-60$ & $45-60$ & $45-60$ \\
\hline Sugar (\%E) & $<11$ & $<11$ & $<11$ \\
\hline Fat $(\% \mathrm{E})$ & $20-35$ & $20-35$ & $20-35$ \\
\hline Saturated fat (\%E) & $<11$ & $<11$ & $<11$ \\
\hline $\mathrm{Na}(\mathrm{mg})$ & $<686$ & $<824$ & $<824$ \\
\hline $\mathrm{Fe}(\mathrm{mg})$ & $>3 \cdot 0$ & $>4 \cdot 4$ & $>4 \cdot 4$ \\
\hline Folate $(\mu \mathrm{g})$ & $>45$ & $>60$ & $>60$ \\
\hline $\mathrm{Zn}(\mathrm{mg})$ & $>2 \cdot 1$ & $>2 \cdot 8$ & $>2 \cdot 8$ \\
\hline Dietary fibre (g) & $>4 \cdot 8$ & $>6 \cdot 3$ & $>7.5$ \\
\hline $\mathrm{Ca}(\mathrm{mg})$ & $>165$ & $>300$ & $>270$ \\
\hline Vitamin A $(\mu \mathrm{g})$ & $>150$ & $>187$ & $>210$ \\
\hline Vitamin C (mg) & $>9$ & $>11$ & $>12$ \\
\hline
\end{tabular}

$\% \mathrm{E}$, percentage of energy intake; $\mathrm{CHO}$, carbohydrate. 
Table 2 Nutritional values for macronutrients in a selection of twenty-five Margherita pizzas, both for a portion sold as standard and as a $2510 \mathrm{~kJ} / 600 \mathrm{kcal}$ portion. Values which lie outside the nutritional recommendations for adult meals are highlighted, either above $(\dagger)$ or below ( $\ddagger)$

\begin{tabular}{|c|c|c|c|c|c|c|c|c|c|}
\hline Pizza & $\begin{array}{l}\text { Portion } \\
\text { (kJ) }\end{array}$ & $\begin{array}{l}\text { Portion } \\
\text { (kcal) }\end{array}$ & $\begin{array}{c}\text { Protein } \\
(\% \mathrm{E})\end{array}$ & $\begin{array}{l}\mathrm{CHO} \\
(\% \mathrm{E})\end{array}$ & $\begin{array}{l}\text { Sugar } \\
(\% \mathrm{E})\end{array}$ & $\begin{array}{l}\text { Fat } \\
(\% \mathrm{E})\end{array}$ & $\begin{array}{l}\text { Saturated } \\
\text { fat }(\% \mathrm{E})\end{array}$ & $\begin{array}{l}\text { Fibre } \\
\text { (g) }\end{array}$ & $\begin{array}{c}\mathrm{Na} \\
(\mathrm{mg})\end{array}$ \\
\hline Amy's Margherita Pizza (organic) $368 \mathrm{~g}$, USA & $\begin{array}{c}1172(1 / 3) \\
2510\end{array}$ & $\begin{array}{c}280(1 / 3) \\
600\end{array}$ & $15 \cdot 7$ & $45 \cdot 7$ & $4 \cdot 3$ & $38.6+$ & $11 \cdot 3+$ & $\begin{array}{l}2 \cdot 0 \\
4 \cdot 3\end{array}$ & $\begin{array}{c}550 \\
1179+\end{array}$ \\
\hline Compliments Mozzarella Pesto Thin Crust Pizza Brick Oven Pizza 336 g, CA & $\begin{array}{c}837(1 / 4) \\
2510\end{array}$ & $\begin{array}{c}200(1 / 4) \\
600\end{array}$ & $20 \cdot 0$ & $48 \cdot 0$ & $6 \cdot 0$ & $31 \cdot 5$ & $13 \cdot 5+$ & $\begin{array}{l}2 \cdot 0 \\
6 \cdot 0\end{array}$ & $\begin{array}{l}320 \\
960+\end{array}$ \\
\hline Conte's Margherita Pizza with Roasted Garlic and Olive Oil 452 g, USA & $\begin{array}{c}921(1 / 4) \\
2510\end{array}$ & $\begin{array}{c}220(1 / 4) \\
600\end{array}$ & $14 \cdot 5$ & $45 \cdot 5$ & $7 \cdot 3$ & $36 \cdot 8 \dagger$ & $14 \cdot 3+$ & $\begin{array}{l}1 \cdot 0 \\
2 \cdot 7\end{array}$ & $\begin{array}{c}550 \\
1500+\end{array}$ \\
\hline Cosmo Pizza Margherita $380 \mathrm{~g}$, UK & $\begin{array}{c}1657(1 / 2) \\
2510\end{array}$ & $\begin{array}{c}396(1 / 2) \\
600\end{array}$ & $20 \cdot 1$ & $48 \cdot 6$ & $1 \cdot 1$ & $34 \cdot 5$ & $15 \cdot 5+$ & $\begin{array}{l}3 \cdot 9 \\
6 \cdot 0\end{array}$ & $\begin{array}{c}676 \\
1001+\end{array}$ \\
\hline Dietary Specials Mozzarella and Tomato Deep Pan Pizza $310 \mathrm{~g}$, UK & $\begin{array}{c}1548(1 / 2) \\
2510\end{array}$ & $\begin{array}{c}370(1 / 2) \\
600\end{array}$ & $9 \cdot 4 \ddagger$ & $70 \cdot 5+$ & $4 \cdot 0$ & $18 \cdot 3 \ddagger$ & $4 \cdot 3$ & $\begin{array}{l}3 \cdot 4 \\
5 \cdot 5\end{array}$ & $\begin{array}{c}960 \\
1558 \dagger\end{array}$ \\
\hline Dr. Oetker Ristorante Mozzarella Pizza, UK & $\begin{array}{c}1845^{\star}(1 / 2) \\
2510^{-1 / 2}\end{array}$ & $\begin{array}{c}441^{*}(1 / 2) \\
600\end{array}$ & $16 \cdot 6$ & $36 \cdot 7 \ddagger$ & $2 \cdot 7$ & $46 \cdot 5+$ & $16 \cdot 1 \dagger$ & $\begin{array}{l}2 \cdot 8 \\
3 \cdot 8\end{array}$ & $\begin{array}{c}800 \\
1088+\end{array}$ \\
\hline Goodfellas Deep Pan Margherita Pizza 410g (frozen), UK & $\begin{array}{c}1042(1 / 4) \\
2510\end{array}$ & $\begin{array}{c}249(1 / 4) \\
600\end{array}$ & $17 \cdot 6$ & $52 \cdot 5$ & $6 \cdot 7$ & $30 \cdot 0$ & $14 \cdot 8+$ & $\begin{array}{l}2 \cdot 4 \\
5 \cdot 9\end{array}$ & $\begin{array}{l}310 \\
765+\end{array}$ \\
\hline Goodfellas Thin Flatbread Light \& Crispy Pizza Margherita $345 \mathrm{~g}$ (frozen), UK & $\begin{array}{c}1025(1 / 4) \\
2510\end{array}$ & $\begin{array}{c}245(1 / 4) \\
600\end{array}$ & $15 \cdot 9$ & $50 \cdot 3$ & $5 \cdot 2$ & $26 \cdot 5$ & $11 \cdot 7 \dagger$ & $\begin{array}{l}1 \cdot 9 \\
4 \cdot 6\end{array}$ & $\begin{array}{l}340 \\
842 \dagger\end{array}$ \\
\hline Goodfellas Stonebaked Thin Margherita Pizza $345 \mathrm{~g}$ (frozen), UK & $\begin{array}{c}1071(1 / 4) \\
2510\end{array}$ & $\begin{array}{c}256(1 / 4) \\
600\end{array}$ & $18 \cdot 5$ & $42 \cdot 8 \ddagger$ & $4 \cdot 7$ & $38.7 t$ & $18 \cdot 4 \dagger$ & $\begin{array}{l}1 \cdot 7 \\
4 \cdot 0\end{array}$ & $\begin{array}{l}340 \\
805+\end{array}$ \\
\hline Kashi Thin Crust Pizza Margherita $339 \mathrm{~g}$, USA & $\begin{array}{c}1088(1 / 3) \\
2510\end{array}$ & $\begin{array}{c}260(1 / 3) \\
600\end{array}$ & $21 \cdot 5$ & $44 \cdot 6 \ddagger$ & $6 \cdot 2$ & $31 \cdot 2$ & $13 \cdot 8+$ & $\begin{array}{l}4 \cdot 0 \\
9 \cdot 2\end{array}$ & $\begin{array}{c}630 \\
1454 \dagger\end{array}$ \\
\hline McCain Family Pizza Margherita $500 \mathrm{~g}, \mathrm{AU}$ & $\begin{array}{c}1381(1 / 4) \\
2510\end{array}$ & $\begin{array}{c}330(1 / 4) \\
600\end{array}$ & $19 \cdot 9$ & $42 \cdot 9 \ddagger$ & $10 \cdot 3$ & $34 \cdot 2$ & $22 \cdot 9+$ & - & $\begin{array}{l}438 \\
797 \dagger\end{array}$ \\
\hline Pizza Express Margherita $245 \mathrm{~g}$, UK & $\begin{array}{c}1201(1 / 2) \\
2510\end{array}$ & $\begin{array}{c}287(1 / 2) \\
600\end{array}$ & $17 \cdot 4$ & $55 \cdot 9$ & $4 \cdot 1$ & $26 \cdot 5$ & $13 \cdot 5+$ & $\begin{array}{l}3 \cdot 3 \\
7 \cdot 0\end{array}$ & $\begin{array}{c}620 \\
1290+\end{array}$ \\
\hline Prima Fresco Margherita $411 \mathrm{~g}$, UK & $\begin{array}{c}2155(1 / 2) \\
2510\end{array}$ & $\begin{array}{c}515(1 / 2) \\
600\end{array}$ & $15 \cdot 8$ & $49 \cdot 1$ & $5 \cdot 9$ & $34 \cdot 9$ & $11 \cdot 2 \dagger$ & $\begin{array}{l}3 \cdot 9 \\
4 \cdot 6\end{array}$ & $\begin{array}{l}600 \\
720+\end{array}$ \\
\hline Tesco Finest Margherita Pizza 306 g, UK & $\begin{array}{c}1715(1 / 2) \\
2510\end{array}$ & $\begin{array}{c}410(1 / 2) \\
600\end{array}$ & $17 \cdot 9$ & $46 \cdot 7$ & $4 \cdot 6$ & $33 \cdot 0$ & $17 \cdot 3+$ & $\begin{array}{l}2 \cdot 8 \\
4 \cdot 0\end{array}$ & $\begin{array}{r}700 \dagger \\
1111+\end{array}$ \\
\hline Tesco Italian Margherita Pizza $310 \mathrm{~g}$, UK & $\begin{array}{c}1757(1 / 2) \\
2510\end{array}$ & $\begin{array}{c}420(1 / 2) \\
600\end{array}$ & $17 \cdot 3$ & $51 \cdot 4$ & $4 \cdot 6$ & $29 \cdot 0$ & $13 \cdot 0+$ & $\begin{array}{l}1 \cdot 6 \\
2 \cdot 2\end{array}$ & $\begin{array}{l}600 \\
889+\end{array}$ \\
\hline Tesco Italian Stonebaked Margherita $445 \mathrm{~g}$, UK & $\begin{array}{c}1297(1 / 4) \\
2510\end{array}$ & $\begin{array}{c}310(1 / 4) \\
600\end{array}$ & $19 \cdot 3$ & $50 \cdot 6$ & $4 \cdot 3$ & $28 \cdot 9$ & $12 \cdot 8+$ & $\begin{array}{l}1 \cdot 1 \\
2 \cdot 1\end{array}$ & $\begin{array}{l}500 \\
857+\end{array}$ \\
\hline Domino's Pizza Cheese \& Tomato - Delight Mozzarella - Medium Regular Crust 503 g, UK & $\begin{array}{c}1364(1 / 4) \\
2510\end{array}$ & $\begin{array}{c}326(1 / 4) \\
600\end{array}$ & $24 \cdot 7$ & $54 \cdot 4$ & $6 \cdot 0$ & $20 \cdot 8$ & $8 \cdot 0$ & $\begin{array}{l}3 \cdot 4 \\
6 \cdot 3\end{array}$ & $\begin{array}{c}560 \\
1019+\end{array}$ \\
\hline Domino's Pizza Cheese \& Tomato - Medium Regular Crust $504 \mathrm{~g}$, UK & $\begin{array}{c}1356(1 / 4) \\
2510\end{array}$ & $\begin{array}{c}324(1 / 4) \\
600\end{array}$ & $20 \cdot 9$ & $52 \cdot 3$ & $6 \cdot 8$ & $26 \cdot 6$ & $12 \cdot 3+$ & $\begin{array}{l}3 \cdot 0 \\
5 \cdot 6\end{array}$ & $\begin{array}{l}500 \\
934 \dagger\end{array}$ \\
\hline Domino's Pizza Cheese \& Tomato - Medium Thin Crust $369 \mathrm{~g}$, UK & $\begin{array}{c}1389(1 / 4) \\
2510\end{array}$ & $\begin{array}{c}320(1 / 4) \\
600\end{array}$ & $18 \cdot 1$ & $41 \cdot 7 \ddagger$ & $4 \cdot 0$ & $40 \cdot 2+$ & $15 \cdot 6+$ & $\begin{array}{l}2 \cdot 8 \\
5 \cdot 0\end{array}$ & $\begin{array}{l}320 \\
605\end{array}$ \\
\hline Pizza Hut Restaurant Margherita Regular Italian, UK & $\begin{array}{c}1423(1 / 3) \\
2510\end{array}$ & $\begin{array}{c}340(1 / 3) \\
600\end{array}$ & $16 \cdot 9$ & $49 \cdot 4$ & $3 \cdot 8$ & $32 \cdot 3$ & $13 \cdot 8+$ & - & $\begin{array}{l}520 \\
918+\end{array}$ \\
\hline Pizza Hut Restaurant Margherita Regular Pan, UK & $\begin{array}{c}1573(1 / 3) \\
2510\end{array}$ & $\begin{array}{c}376(1 / 3) \\
600\end{array}$ & $16 \cdot 0$ & $42 \cdot 6 \ddagger$ & $2 \cdot 3$ & $41 \cdot 6+$ & $14 \cdot 8+$ & - & $\begin{array}{l}536 \\
855+\end{array}$ \\
\hline allrecipes.co.uk ‘Easy Pizza’ & $\begin{array}{c}1287(1 / 2) \\
2510\end{array}$ & $\begin{array}{c}308(1 / 2) \\
600\end{array}$ & $19 \cdot 5$ & $51 \cdot 3$ & $6 \cdot 3$ & $32 \cdot 4$ & $19 \cdot 7 \dagger$ & $\begin{array}{l}1 \cdot 8 \\
3 \cdot 5\end{array}$ & $\begin{array}{l}345 \\
672\end{array}$ \\
\hline allrecipes.co.uk 'Margherita Pizza' & $\begin{array}{c}1075(1 / 4) \\
2510\end{array}$ & $\begin{array}{c}257(1 / 4) \\
600\end{array}$ & $15 \cdot 2$ & $57 \cdot 6$ & $4 \cdot 7$ & $28 \cdot 8$ & $12 \cdot 1 \dagger$ & $\begin{array}{l}2 \cdot 2 \\
5 \cdot 1\end{array}$ & $\begin{array}{l}226 \\
526\end{array}$ \\
\hline bbcgoodfood.com 'Ultimate Pizza Margherita' & $\begin{array}{c}2451(1 / 2) \\
2510\end{array}$ & $\begin{array}{c}562(1 / 2) \\
600\end{array}$ & $18 \cdot 2$ & $54 \cdot 0$ & $3 \cdot 5$ & $31 \cdot 2$ & $16 \cdot 5+$ & $\begin{array}{l}4 \cdot 4 \\
4 \cdot 7\end{array}$ & $\begin{array}{l}1120+ \\
1196+\end{array}$ \\
\hline
\end{tabular}

$\% \mathrm{E}$, percentage of energy intake; $\mathrm{CHO}$, carbohydrate.

*Portion size sold as standard in France, Greece, Ireland and the UK. Portion size sold as standard in Canada: 1/4 pizza (921 kJ/220 kcal), USA: 1/3 pizza (1213 kJ/290 kcal), Germany, Spain: 1 pizza (3728 kJ/891 kcal). 
a notional $2510 \mathrm{~kJ} / 600 \mathrm{kcal}$ serving of each pizza studied. The main nutrient information, often available on product packaging and relevant to healthy eating, is on saturated fat, carbohydrate, fibre and salt (Na). New labelling legislation (under the EU Food Information for Consumer Regulation), effective from 2016 onwards, will make back-of-pack nutritional information mandatory for these nutrients. Overall, our results are in line with a previous survey of pizzas ${ }^{(23)}$. Perhaps surprisingly, only six of the twenty-five pizzas contain too much total fat $(>35 \% \mathrm{E})$. The other nineteen values are often close to the limit but within the recommendations. On the other hand, only two pizzas in the selection contain a desirable proportion of saturated fat, i.e. below $11 \% \mathrm{E}^{(13)}$. Nineteen of the twenty-five $(76 \%)$ have saturated fat content above $11 \% \mathrm{E}$, and many are close to the recommendation e.g. $11-15 \% \mathrm{E}$, but only eight are very high, above $15 \% \mathrm{E}$. The range of saturated fat content, from $4 \cdot 3$ to $22 \cdot 9 \% \mathrm{E}$, is wide, indicating considerable scope for improvement by recipe modifications. Most of the fat and saturated fat comes from the cheese topping, with a small contribution from oil.

The amount of $\mathrm{Na}$ in most of the twenty-five pizzas is substantially above the recommended limit for a meal (Table 1). The source of $\mathrm{Na}$ is mainly the cheese topping, although extra salt is also routinely added to both the dough and sauce topping. Nine of the twenty-five pizzas contain more than $1 \mathrm{~g} \mathrm{Na}$ per $2510 \mathrm{~kJ} / 600 \mathrm{kcal}$ serving. On the other hand, several of these pizzas (all standard pizzas, not part of a healthy range or making a 'lowsodium or low-salt' claim) have Na content well within the recommended limit. Again this indicates that there is scope to modify the current recipes and remain commercially successful with a much lower Na content.

To constitute a healthy nutritionally balanced meal, at least $45 \%$ of the energy intake should come from carbohydrate (Table 1). Only five pizzas in twenty-five fail to reach this proportion, mainly because their fat and protein contents (combined) are too high. The quantity of fibre in these pizzas varies very substantially from $2 \cdot 1$ to $9 \cdot 2 \mathrm{~g}$ per $2510 \mathrm{~kJ} / 600 \mathrm{kcal}$ serving. This variation depends on the source and quantity of tomato and flour used. Other ingredients supply little or no dietary fibre.

The compositional values for vitamins and minerals are usually absent from the nutritional information tables provided on pizza packaging. These values were provided for only five pizzas out of the twenty-five for which recipes are provided, and limited information was available for three others from the commercial range. For these eight pizzas, vitamin contents vary widely, with none meeting the combined nutritional recommendations for Fe, vitamin C and vitamin A (Table 3). Only one pizza meets the recommended value for $\mathrm{Fe}$, and two the recommended value for vitamin $\mathrm{C}$. Recommendations for vitamin A are met by four out of the eight pizzas, while all but one meets recommendations for $\mathrm{Ca}$.

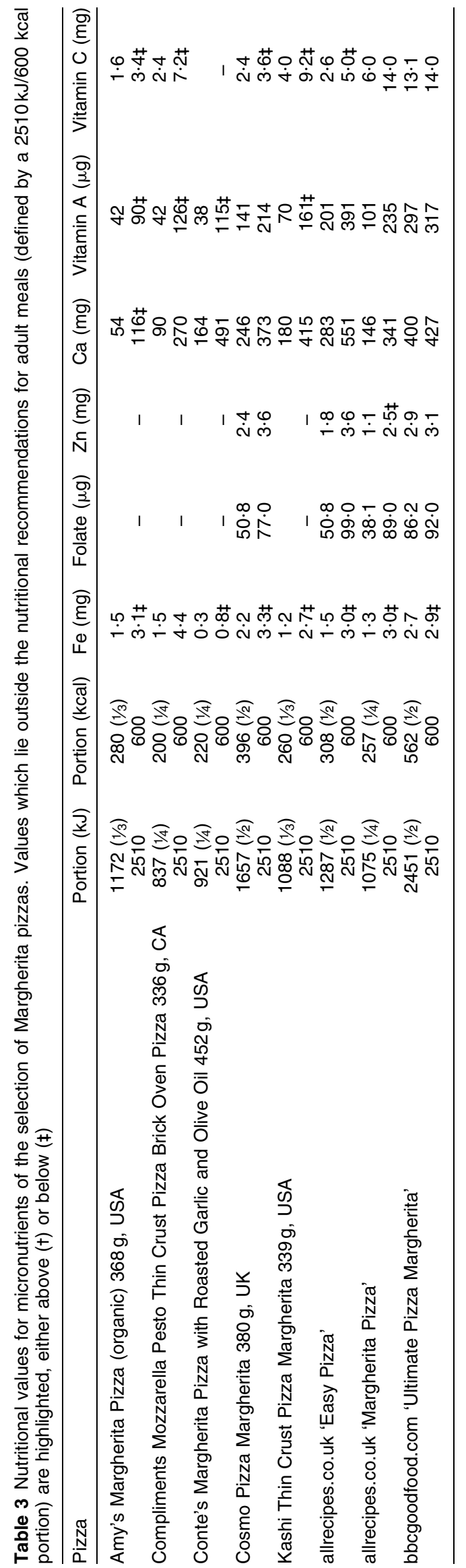


Our overview of these twenty-five Margherita pizzas indicates that, while none of them matches all the nutritional recommendations for a healthy meal, many already meet several of the criteria, with several more being close to all criteria. The energy content of commercial portions varies however and may not match consumer needs, depending on whether the pizza is consumed as a single-item meal or not. If not, side-item selection may be difficult given the variable energy content of the different pizza products. There is clearly wide variation in the 'healthfulness' of commonly available pizzas in relation to cardiovascular risks; e.g. saturated fat content ranging between $4 \cdot 3$ to $22 \cdot 9 \% \mathrm{E}$ and $\mathrm{Na}$ from 526 to $1558 \mathrm{mg}$ in a $2510 \mathrm{~kJ} / 600 \mathrm{kcal}$ 'meal-sized' portion. However, there is also clearly scope, using traditional ingredients, to modify recipes to meet nutritional targets.

Bearing in mind the frequency of pizza consumption by young people and the documented prevalence of nutritional deficiencies in young people (particularly $\mathrm{Fe}$, $\mathrm{Ca}, \mathrm{Mg}$ and vitamin $\mathrm{A})^{(24)}$, there is a clear case for trying to apply the nutritional standards which already exist for meals (Table 1). If it is practically and commercially possible for pizzas to provide these nutrients, there seems no reason to continue to make nutritionally unbalanced pizzas.

\section{Dietary modification of a commercial pizza recipe to achieve a balanced meal}

To explore the possible ways to provide a nutritionally balanced pizza meal, the Margherita recipe currently used by a local pizza manufacturer (Cosmo Products Ltd, UK) was examined in more detail (Table 3 ). The pizza, made using a traditional recipe and method, is currently sold as a half-pizza portion ( 9 inch diameter), containing about $1674 \mathrm{~kJ}$ ( $400 \mathrm{kcal})$. It is acceptable for the primary and secondary school market, where the average energy per meal is either 2330 or $2791 \mathrm{~kJ}(557$ or $667 \mathrm{kcal})$, respectively, if consumed alongside a starter and/or a pudding. The current total fat content, as a proportion of the total energy of the pizza itself, is just acceptable, at the limit of $35 \% \mathrm{E}$ (which, based on the 1991 report of the Committee on Medical Aspects of Food and Nutrition Policy, would apply to the fat intake of a population over several days and is not designed to be a limit for a single meal, yet is a potential useful benchmark ${ }^{(25)}$ ), but the proportion of energy from saturated fat is too high. A $2510 \mathrm{~kJ} / 600 \mathrm{kcal}$ portion would contain too much $\mathrm{Na}$ and protein, and too little Fe and vitamin C (based on the Dietary Reference Values set in the 1991 Committee on Medical Aspects of Food and Nutrition Policy report, designed for population intake and not designed for single meals, as mentioned above).

The pizza recipe was reformulated to a prototype balanced pizza, for which the nutrient composition is shown in Table 4. While a useful source of $\mathrm{Ca}$ and vitamin A, the mozzarella cheese on the pizza is also the main source of saturated fat and protein and contributes to the overall $\mathrm{Na}$ content. To reach an adequate proportion of saturated fat, the quantity of mozzarella was reduced; hence a relative increase of the breadto-topping ratio. Salt was decreased in both the dough and sauce. Addition of red peppers mixed into the tomato sauce enabled the recommended amount of vitamin $\mathrm{C}$ to be reached. Incorporating whole-wheat flour

Table 4 Nutrient contents, estimated from food composition tables (WinDiets 2005) and by laboratory analysis, for the prototype balanced Margherita pizza and the final retail product

\begin{tabular}{|c|c|c|c|c|c|}
\hline \multirow[b]{3}{*}{ Nutrient } & \multicolumn{3}{|c|}{ Prototype recipe } & \multirow{3}{*}{$\begin{array}{l}\text { FSA guidelines } \\
\text { (adults) }\end{array}$} & \multirow[b]{2}{*}{ Final recipe } \\
\hline & \multirow[b]{2}{*}{ Dietary analysis (per pizza) } & \multicolumn{2}{|c|}{ Laboratory analysis (per cooked pizza) ${ }^{*}$} & & \\
\hline & & Mean & SD & & Dietary analysis (per pizza) \\
\hline Energy (kJ/kcal) & $2797 / 664$ & $2810 / 667$ & $34 / 14$ & $2510 / 600 t$ & $2163 / 513$ \\
\hline Fat $(\% \mathrm{E})$ & $29 \cdot 3$ & $19 \cdot 6$ & 0.4 & 20-35 & $27 \cdot 3$ \\
\hline Saturated fat (\%E) & $11 \cdot 0$ & $6 \cdot 5$ & 0.4 & $<11$ & $10 \cdot 2$ \\
\hline Protein (\%E) & $17 \cdot 8$ & $21 \cdot 4$ & 0.7 & $>12$ & $17 \cdot 2$ \\
\hline $\mathrm{CHO}(\% \mathrm{E})$ & $56 \cdot 8$ & $67 \cdot 0$ & $2 \cdot 7$ & $45-60 t$ & $56 \cdot 2$ \\
\hline NMES (\%E) & $1 \cdot 3$ & $3 \cdot 4$ & 0.5 & $<11$ & $2 \cdot 9$ \\
\hline NSP+DF (g) & 8.5 & $13 \cdot 7$ & $2 \cdot 6$ & $>7 \cdot 5$ & $7 \cdot 5$ \\
\hline Vitamin A $(\mu \mathrm{g})$ & 343 & $427 \cdot 5$ & $34 \cdot 2$ & $>210$ & 465 \\
\hline Vitamin C (mg) & $13 \cdot 3$ & $11 \cdot 7$ & 0.6 & $>12 t$ & $27 \cdot 8$ \\
\hline Folate $(\mathrm{mg})$ & $96 \cdot 0$ & $62 \cdot 7$ & $3 \cdot 1$ & $>60$ & 194 \\
\hline $\mathrm{Ca}(\mathrm{mg})$ & 349 & $547 \cdot 2$ & $14 \cdot 3$ & $>270$ & 280 \\
\hline $\mathrm{Na}(\mathrm{mg})$ & 817 & $1023 \cdot 2$ & $17 \cdot 1$ & $<824 \ddagger$ & 473 \\
\hline $\mathrm{Fe}(\mathrm{mg})$ & 4.9 & $6 \cdot 4$ & 0.6 & $>4 \cdot 4$ & $5 \cdot 3$ \\
\hline $\mathrm{Zn}(\mathrm{mg})$ & $3 \cdot 8$ & $5 \cdot 8$ & 0.3 & $>2 \cdot 8$ & $3 \cdot 5$ \\
\hline
\end{tabular}

FSA, Food Standards Agency; \%E, percentage of energy intake; CHO, carbohydrate, NMES, non-milk extrinsic sugars; DF, dietary fibre.

${ }^{*}$ Results expressed as means and standard deviations. Results are representative of triplicated analysis of duplicate samples.

†These nutrients were deemed to vary too much from the FSA guideline. The prototype recipe was modified to correct this and validated by WinDiets 2005 dietary analysis only.

$\ddagger$ This nutrient was deemed to vary too much from the FSA guideline. The prototype recipe was modified to correct this, and validated by both WinDiets 2005 dietary analysis and laboratory analysis. 
Table 5 Full nutritional analysis, estimated from food composition tables (WinDiets 2005), of the final reformulated nutritionally balanced Margherita pizza

\begin{tabular}{|c|c|c|c|}
\hline Nutrient & Units & Dietary analysis (per pizza) & $30 \% \mathrm{DRV} / \mathrm{RDA}$ \\
\hline Energy & $\mathrm{kJ} / \mathrm{kcal}$ & $2163 / 513$ & $2510 / 600$ \\
\hline Fat & $\mathrm{g} / \% \mathrm{E}$ & $15 \cdot 7 / 27 \cdot 3$ & 21 \\
\hline SFA & $g / \% E$ & $6 \cdot 0 / 10 \cdot 2$ & 6 \\
\hline PUFA & $\mathrm{g} / \% \mathrm{E}$ & $2 \cdot 9 / 5 \cdot 1$ & \\
\hline MUFA & $g / \% E$ & $5 \cdot 5 / 10 \cdot 2$ & \\
\hline Protein & $g / \% E$ & $22 \cdot 2 / 17 \cdot 2$ & $13 \cdot 5$ \\
\hline $\mathrm{CHO}$ & $\mathrm{g} / \% \mathrm{E}$ & $76 \cdot 1 / 56 \cdot 2$ & 69 \\
\hline Total sugars & $\mathrm{g} / \% \mathrm{E}$ & $7 \cdot 3 / 5 \cdot 1$ & 27 \\
\hline NMES & $\mathrm{g} / \% \mathrm{E}$ & $3.9 / 2.9$ & \\
\hline $\mathrm{NSP}+\mathrm{DF}$ & g & $7 \cdot 5$ & $7 \cdot 2$ \\
\hline Vitamin A & $\mu g$ & 465 & 240 \\
\hline Vitamin C & $\mathrm{mg}$ & $27 \cdot 8$ & 24 \\
\hline Vitamin D & $\mu \mathrm{g}$ & $0 \cdot 1$ & 1.5 \\
\hline Vitamin E & $\mathrm{mg}$ & $4 \cdot 4$ & $3 \cdot 6$ \\
\hline Thiamin & $\mathrm{mg}$ & 0.6 & 0.3 \\
\hline Riboflavin & $\mathrm{mg}$ & 0.4 & $0 \cdot 42$ \\
\hline Niacin & $\mathrm{mg}$ & $10 \cdot 6$ & $4 \cdot 8$ \\
\hline Vitamin $\mathrm{B}_{6}$ & $\mathrm{mg}$ & 0.6 & $0 \cdot 4$ \\
\hline Vitamin $B_{12}$ & $\mu g$ & $0 \cdot 7$ & $0 \cdot 8$ \\
\hline Folate & $\mu \mathrm{g}$ & 194 & 60 \\
\hline Pantothenic acid & $\mathrm{mg}$ & $1 \cdot 4$ & $1 \cdot 8$ \\
\hline Biotin & $\mu \mathrm{g}$ & $13 \cdot 5$ & 15 \\
\hline $\mathrm{Ca}$ & $\mathrm{mg}$ & 280 & 240 \\
\hline $\mathrm{Mg}$ & $\mathrm{mg}$ & 112 & $112 \cdot 5$ \\
\hline $\mathrm{Na}$ & $\mathrm{mg}$ & 473 & 720 \\
\hline $\mathrm{K}$ & $\mathrm{mg}$ & 813 & 600 \\
\hline $\mathrm{Cl}$ & $\mathrm{mg}$ & 816 & 240 \\
\hline$P$ & $\mathrm{mg}$ & 413 & 210 \\
\hline $\mathrm{Fe}$ & $\mathrm{mg}$ & $5 \cdot 3$ & $4 \cdot 2$ \\
\hline $\mathrm{Zn}$ & $\mathrm{mg}$ & $3 \cdot 5$ & $3 \cdot 0$ \\
\hline $\mathrm{Cu}$ & $\mathrm{mg}$ & 0.65 & $0 \cdot 3$ \\
\hline $\mathrm{Mn}$ & $\mathrm{mg}$ & $2 \cdot 11$ & 0.6 \\
\hline $\mathrm{Se}$ & $\mu \mathrm{g}$ & $7 \cdot 0$ & $16 \cdot 5$ \\
\hline lodine & $\mu \mathrm{g}$ & 678 & 45 \\
\hline Cholesterol & $\mathrm{mg}$ & 23 & 100 \\
\hline Retinoids & $\mu \mathrm{g}$ & 98 & \\
\hline Carotenoids & ug & 1131 & \\
\hline
\end{tabular}

DRV, Dietary Reference Value; $\mathrm{CHO}$, carbohydrate, NMES, non-milk extrinsic sugars; DF, dietary fibre; \%E, percentage of energy intake.

and a small amount of dried seaweed into the dough achieved the recommended quantities of fibre, Fe and vitamin $\mathrm{A}$, also increasing the iodine and vitamin $\mathrm{B}_{12}$ contents of the pizza.

The values obtained for the prototype recipe, using standard tables of nutrient compositions (WinDiets 2005), were confirmed for a range of nutrients by laboratory analyses using standard methods and compared with the FSA guidelines for nutrient composition of the adult meal. The outcomes of the laboratory analyses were similar to those values obtained using food tables for many nutrients, but varied significantly for vitamin C, folate, Ca and $\mathrm{Na}$, probably due to factors such as variability of the nutrient composition of the key ingredients and the impact of processing/cooking on some vitamins. Heat processing may increase the concentrations of some nutrients due to loss of moisture, but reduce others through compositional changes such as Maillard reactions and loss of volatiles (e.g. iodine) or heat-sensitive nutrients. Comparison of each nutrient with the FSA guideline highlighted that energy, carbohydrate, vitamin $\mathrm{C}$ and $\mathrm{Na}$ varied either marginally or significantly from the guidelines. The prototype pizza recipe was then modified to address these departures from guidelines, and the nutrient composition of the final recipe was confirmed using standard tables of nutrient compositions (WinDiets 2005). The Na content, shown by laboratory analysis to be significantly higher than expected in the prototype, was re-confirmed in the final product by atomic absorption spectroscopy (at an acceptable level of $427.5 \mathrm{mg}$ per pizza). Tables 4 and 5 show nutrient contents across the steps taken from the original template through to the prototype and final pizza recipe.

\section{Acceptability of the reformulated balanced pizza}

The reformulated pizza is only slightly different in appearance and virtually identical in taste to the original pizza recipe, and is still prepared using traditional Italian baking methods. A total of sixty-three children and fortynine adults, in two locations within Greater Glasgow (West End and Clydebank), tasted the pizza and filled in the feedback form. The median age for children was 9 years 
Table 6 Acceptability of the reformulated pizza by members of the public: data on a scale from 1 to 9 , presented as mode and interquartile range (IQR)

\begin{tabular}{lccccc}
\hline & \multicolumn{2}{c}{ Children $(n$ 63) } & & \multicolumn{2}{c}{ Adults $(n$ 49) } \\
\cline { 2 - 3 } \cline { 5 - 6 } & Mode & IQR & & Mode & IQR \\
\hline Appearance of the pizza & 9 & 2 & & 8 & 1 \\
Taste of the pizza & 9 & 2 & & 8 & 1 \\
Overall score & 9 & 2 & & 8 & 1 \\
\hline
\end{tabular}

(interquartile range 4 years, range $3-14$ years) and for adults 35 years (interquartile 16.5 years, range $19-70$ years). The gender split was $59 \%$ females and $41 \%$ males for children, and $69 \%$ females and $31 \%$ males for adults.

The pizza was rated very highly for both appearance and taste by both children and adult tasters, achieving modes of 9 and 8, respectively, with narrow interquartile ranges (2 and 1, respectively; Table 6). Among the children, $46 \%$ rated the pizza as good as their usual one and $35 \%$ rated it better (i.e. $81 \%$ at least as good as), moreover $41 \%$ would eat the pizza instead of their usual one. Most adults (57\%) rated the pizza as good as their usual one, with $20 \%$ better (i.e. $77 \%$ found it at least as good as their usual pizza); $69 \%$ of the adults would buy it instead of their usual one. Most would be willing to pay an extra 50 pence for a nutritionally balanced pizza.

The children liked best the taste (48\%) and the cheese (19\%), while the adults liked best the taste (39\%), the dough/base (20\%) and the tomatoes/sauce (16\%). About a third (30\%) of children responded 'nothing' when asked what they liked least about the pizza, with other children mentioning that they liked least the tomatoes/ sauce (14\%), appearance (11\%) or dough/base (10\%). About a quarter of adults (27\%) responded 'nothing' when asked what they liked least about the pizza, others mentioning that they liked least the base/dough (31\%) or taste/lack of taste (12\%).

Our study therefore shows that, perhaps contrary to popular opinion, it is perfectly possible to have an attractive, nutritionally balanced meal as a single-item pizza meal. Indeed, sensory attributes (appearance, flavour, odour) have been shown to influence the likelihood of consumer purchasing reformulated healthier ready-meal versions ${ }^{(26)}$. The high consumer acceptability of this product is therefore vital and consistent with previous research showing that altering the amount of cheese and crust on a regular pepperoni pizza had no detrimental impact on consumer acceptance of the product ${ }^{(27)}$.

\section{The balanced pizza - potential for bealth by stealth}

In the case of the popular Margherita pizza, it was possible, although quite difficult, to reach all of the recommendations within a feasible pizza portion size. We specifically applied this approach to a single-item pizza meal and achieved that through subtle, and essentially undetectable, modifications to the traditional recipe and the incorporation of small amounts of functional ingredients, specifically red pepper and seaweed (affording an improved nutritional composition to the Margherita pizza and broadening its polyphenolic and carotenoid profile beyond traditional ingredients). However, the physical size or bulk of a $2510-2791 \mathrm{~kJ}(600-667 \mathrm{kcal})$ meal-sized portion may be too large for some consumers. An alternative two-component solution also allows the design of nutritionally balanced Margherita pizza-based meals by adding another item, like a side serving of salad or vegetables, a yoghurt or a piece of fruit. Both of these solutions could be achievable within current meal pricing in economy price ranges. And they should immediately become the preferred pizzas for health promotion and for provision for schools and other mass catering. There is no justification for supplying nutritionally undesirable alternatives.

Historically, salt played a key role in the taste of the pizza in the days when salt was added to most foods, as well as a role in the process of bread-making. By its hygroscopic properties, salt indeed improves the plastic properties of the dough during the mixing process and it allows a better preservation after baking too. With modern temperature-controlled ovens, this function from salt is less necessary. The lower $\mathrm{Na}$ contents of other successful pizzas indicate that it is possible to reduce the content to within the recommended limit.

The main source of vitamin C in the Margherita pizza is tomato, but tomato is in fact a relatively poor source of vitamin $\mathrm{C}$. To reach the recommended amount of vitamin $\mathrm{C}$, the amount of tomato would be impractically large, so the addition of another item was necessary. Red pepper is a convenient and cheap ingredient, rich in vitamin $\mathrm{C}$, which was added in small amounts to the tomato sauce. This was shown not to affect taste or acceptability.

Fe deficiency is a common problem in young and older people alike ${ }^{(13)}$, and the low Fe content, common to all Margherita recipes, is problematic if only the traditional ingredients are used. The amount required for a nutritionally balanced meal is substantially greater than currently present and can only be reached by adding an ingredient which is very rich in $\mathrm{Fe}$, but which does not corrupt the other nutrient balances, looks, taste or practical issues around baking. Most ingredients rich in $\mathrm{Fe}$ would significantly change the appearance and taste of a Margherita pizza, either by radically increasing the amount of bread base with extra wheat flour or by adding meat which is not acceptable to many and certainly no longer 'Margherita'. Meat such as ham would add further to the $\mathrm{Na}$ and fat contents. Using a small amount of A. nodosum, a common seaweed in the UK and Europe, enabled us to achieve the required target for $\mathrm{Fe}$. In addition, the seaweed used here (Seagreens ${ }^{\circledR}$ ) is a source of vitamin $\mathrm{A}$, $\mathrm{Ca}$ as well as iodine (a nutrient lacking in the British diet) ${ }^{(28)}$. 
Health promotion based on nutritional education only has had rather little impact and a more potent alternative strategy lies in modification of the food supply ${ }^{(7,29,30)}$. Achieving the meeting of nutritional guidelines by stealth - via reformulation of common foods - rather than by an education-based strategy only is indeed promising, but this has not been supported in general by the food industry. There is however scope to modify the composition of specific products and the present project appears to be the first to have done so for a single-item meal. The process we have demonstrated is versatile and lends itself to a range of nutritionally balanced pizza meals beyond the simple Margherita. Commercial opportunities lie in the creation of a premium range of pizzas for the health-conscious customer seeking convenience and taste. We have demonstrated that nutritionally balanced pizza recipes are achievable and suggest that these should become the standard to which all others would aspire: in principle, there is no reason for continuing to sell nutritionally unbalanced pizzas. It will therefore be important to extend the type of work presented here to different recipes and among wider consumer groups to test acceptability. When respected public bodies such as the BBC publish recipes on their websites, it would serve the public best for those recipes to be considered from a nutritional perspective.

A nutritionally balanced meal may still require a degree of moderation when consumed. The weight-conscious consumer must limit himself/herself to the $2510 \mathrm{~kJ} /$ $600 \mathrm{kcal}$ serving of pizza meal and avoid unwanted energy intake from high-energy snacks and drinks which are currently heavily promoted at pizza outlets. For example, a full-fat latté coffee $(340 \mathrm{ml})$ contains about $837 \mathrm{~kJ}$ (200 kcal) and a standard serving of carbonated cola or 'soda' $(330 \mathrm{ml})$ contains about $586 \mathrm{~kJ}(140 \mathrm{kcal})$. While a full pizza may provide the required energy and nutrients for a meal, it does not stop consumers exploring a range of meal compositions, including for example a side salad and fruits to accompany a portion of the pizza. Indeed, here we described a single-item pizza meal. However, this is only one way to ensure that recommendations are met. Most consumers are failing to achieve the FSA guidelines at present, under advice that meals need not all be nutritionally balanced but should complement one another to construct a nutritionally balanced overall diet. The single-item pizza meal presented here is an innovative solution, never offered previously, which might be appropriate for some consumer sectors.

\section{Conclusion}

The data presented here suggest that there is scope to improve ready meals, which are currently mostly nutritionally unacceptable. There is increasing pressure for food manufacturers to limit the amount of $\mathrm{Na}$ added to these products and to adopt a more health-conscious approach when formulating products. The nutritionally balanced pizza was developed with industrial partners and has successfully reached market. The results of the study confirm that consumers are willing to adopt nutritionally balanced pizzas, providing opportunities for the food industry to develop tailor-made, functional products, thereby increasing their innovation and competitiveness.

\section{Acknowledgements}

Sources of funding: This project was supported by a 'First Step Award' (funding from the University of Glasgow and the Scottish Government) between the University of Glasgow and the industrial partner Eat Balanced Ltd. Eat Balanced Ltd had no role in the design, analysis or writing of this article. Conflicts of interest: The authors declare no conflict of interest. Subsequent to this project, M.E.J.L. has acted as scientific advisor for Eat Balanced Ltd and received a consultancy fee from the company. Ethics: Ethical approval was not required. Authors' contributions: M.E.J.L. developed the concept. E.C. and M.E.J.L. supervised A.J., who carried out the dietary analysis and reformulation. K.E.A. carried out the nutritional analysis. E.C., M.E.J.L. and A.J. wrote the manuscript, which was approved by all authors. Acknowledgements: The authors wish to thank Fiona Alexander, UKAS research technician at Glasgow Caledonian University, and the input of Cosmo Tamburro at Cosmo Products Ltd.

\section{References}

1. Devine CM, Nelson JA, Chin N et al. (2007) 'Pizza is cheaper than salad': assessing workers' views for an environmental food intervention. Obesity (Silver Spring) 15. Suppl. 1, 57S-68S.

2. Celnik D, Gillespie L \& Lean M (2012) Time scarcity, ready meals, ill-health and the obesity epidemic. Trends Food Sci Technol 27, 4-11.

3. Gallus S, Bosetti C, Negri E et al. (2003) Does pizza protect against cancer? Int J Cancer 107, 283-284.

4. Gallus S, Tavani A \& La Vecchia C (2004) Pizza and risk of acute myocardial infarction. Eur J Clin Nutr 58, 1543-1546.

5. Moskowitz HR \& Chandler JW (1978) Consumer perceptions, attitudes, and trade-offs regarding flavor and other product characteristics. Food Technol 32, 34-37.

6. Moshfegh AJ, Holden JM, Cogswell ME et al. (2012) Vital signs: food categories contributing the most to sodium consumption - United States, 2007-2008. MMWR Morb Mortal Wkly Rep 61, 92-98.

7. Combris P, Goglia R, Henini M et al. (2011) Improvement of the nutritional quality of foods as a public health tool. Public Health 125, 717-724.

8. Buttriss JL (2013) Food reformulation: the challenges to the food industry. Proc Nutr Soc 72, 61-69.

9. van Raaij J, Hendriksen M \& Verhagen H (2009) Potential for improvement of population diet through reformulation of commonly eaten foods. Public Health Nutr 12, 325-330.

10. World Health Organization (2003) Diet, Nutrition and the Prevention of Chronic Diseases. Joint WHO/FAO Expert 
Consultation. WHO Technical Report Series no. 916. Geneva: WHO.

11. Nielsen SJ, Siega-Riz AM \& Popkin BM (2002) Trends in food locations and sources among adolescents and young adults. Prev Med 35, 107-113.

12. Singh P \& Goyal GK (2011) Functionality of pizza ingredients. Br Food J 113, 1322-1338.

13. Food Standards Agency (2007) FSA nutrient and food based guidelines for UK institutions. http://www.food.gov.uk/ multimedia/pdfs/nutrientinstitution.pdf (accessed May 2013).

14. Scottish Government (2008) Healthy Eating in Schools: A Guide to Implementing the Nutritional Requirements for Food and Drink in Schools (Scotland) Regulations. http:// www.scotland.gov.uk/Publications/2008/09/12090355/0 (accessed May 2013).

15. Horwitz W (ed.) (2000) Official Methods of Analysis of $A O A C$ International, 17th ed. Gaithersburg, MD: AOAC International.

16. Lee SC, Prosky L \& DeVries JW (1992) Determination of soluble, insoluble, and total dietary fiber in foods and food products: collaborative study. J AOAC Int 75, 395-416.

17. Kirk RS \& Sawyer R (1991) Pearson's Composition and Analysis of Foods, 9th ed., pp. 33-34. Harlow: Longman Scientific \& Technical.

18. Dalton FF \& Malanoski AJ (1969) Atomic absorption analysis of copper and lead in meat and meat products. J Association Official Analytical Chemists 52, 1035.

19. DeVries JW \& Silvera KR (2002) Determination of vitamins A (retinol) and $\mathrm{E}$ ( $\alpha$-tocopherol) in foods by liquid chromatography: collaborative study. J AOAC Int $\mathbf{8 5}, 424-434$.

20. Peryam DR \& Pilgrim FJ (1957) The hedonic scale method of measuring food preference. Food Technol 11, Suppl., $9-14$.
21. Lawless H \& Heymann H (1998) Sensory Evaluation of FoodPrinciples and Practice. New York: Chapman and Hall.

22. Kroll BJ (1990) Evaluating rating scales for sensory testing with children. Food Technol 44, 78-86.

23. Food Standards Agency (2004) Programme of mini surveys: pizza survey. Food Survey Information Sheet. http:// www.food.gov.uk/multimedia/pdfs/fsis5804.pdf (accessed May 2013).

24. Department of Health \& Food Standards Agency (2011) National Diet and Nutrition Survey. Headline results from Years 1 and 2 (combined) of the Rolling Programme (2008/ 2009 - 2009/10) [B Beverley Bates, A Lennox, C Bates et al., editors]. https://www.gov.uk/government/publications/ national-diet-and-nutrition-survey-headline-results-fromyears-1-and-2-combined-of-the-rolling-programme-2008-92009-10 (accessed May 2013).

25. Ashwell M (1991) The COMA Report on Dietary Reference Values. Nutr Bull 16, 132-135.

26. Olsen NV, Menichelli E, Sorheim O et al. (2012) Likelihood of buying healthy convenience food: an at-home testing procedure for ready-to-heat meals. Food Qual Prefer 24, 171-178.

27. Goto K \& Bianco-Simeral S (2011) Acceptance of a healthier substitute for regular pepperoni pizza among campus consumers. Calif J Health Promot 9, 9-17.

28. Vanderpump MP, Lazarus JH, Smyth PP et al. (2011) Iodine status of UK schoolgirls: a cross-sectional survey. Lancet 377, 2007-2012.

29. Keller I \& Lang T (2008) Food-based dietary guidelines and implementation: lessons from four countries - Chile, Germany, New Zealand and South Africa. Public Health Nutr 11, 867-874.

30. Sibbel A (2012) Public nutrition and the role of the food industry. Br Food J 114, 784-797. 